\title{
Self-Directed Learning of Mothers' Using Social Media as Parenting Guide in Bali, Indonesia
}

\author{
Luh Putu Laksmi Prema Dewi ${ }^{1 *}$, Puji Yanti Fauziah ${ }^{2}$ \\ ${ }^{1}$ Early Childhood Education, Graduate School, Yogyakarta State University, Indonesia \\ ${ }^{2}$ Non-formal Education Department, Yogyakarta State University, Indonesia \\ *Corresponding author. Email: laksmipremadewi@gmail.com
}

\begin{abstract}
This study aims to describe the perception of young mothers towards the influence of social media as source of information or parenting guide. This research was conducted using qualitative approach. Participants of this study were 24 young mothers who have been selected through purposive sampling technique. Data were collected using focus group discussion (FGD) and in-depth interview. Data were coded into several themes: (1) reasons of using social media as parenting information; (2) types of contents accessed by mothers on parenting accounts; (3) implications of parenting accounts. The result showed that there are ten main reasons of using social media as parenting information. Furthermore, there three types of contents accessed by mothers on parenting accounts including pregnancy, parenting, and family life. Lastly, there are two implications of parenting accounts mentioned by the participants namely: overload information and non-accountable parenting accounts.
\end{abstract}

Keywords: Parenting, Mothers, Social Media, Postnatal

\section{INTRODUCTION}

During these past few years, social activity and internet are intertwined. Internet is considered to make easier for humans accessing various informations, communication media, and providing entertainment. One of the communication media that is widely used nowadays is social media such as WhatsApp, Facebook, Instagram, Twitter, and many others.

According to Kamus Besar Bahasa Indonesia (KBBI) [1], social media is defined as a page or application that allows users to create and share content or get involved in social networks. Furthermore, Boyd \& Ellison [2] stated that social media is a platform to create profiles, make explicit and traverse relationships.

Based on the report of the Indonesian Internet Service Providers Association (APJII) in 2018, top three reasons of using internet are: (1) messaging (24.7\%); (2) accessing social media platforms (18.9\%); (3) browsing information (11.5\%).

The intention to look for information is considered as self-directed learning and happens among household, especially for those who just became parents. Certainly motherhood is rewarding, yielding for many mothers feelings of achievement and meeting societal expectations as well as fun, affection, and companionship (Petch \& Halford, 2008). Parenthood also brings many challenges, including infant care demands, a decline in disposable income, reduced frequency and quality of leisure and couple time, and poorer couple communication [3].

Brooks [4] defines parents as individuals who nurture, protect, and guide a new life towards maturity. Parents make ongoing investments and commitments during their children's long growing years to provide responsible care that includes on-going relationships with the child, material resources, intellectual and moral education, and preparation to take on adult responsibilities. For these new parents, parenting is a new experience that is challenging and will take their time to deal with.

In the other hand, parenting is defined by Brooks [4] as a process of action and interaction between parent and child, where both parties change each other as the child grows into adulthood. So there is collaboration between parents and children, parents nurture and educate until the child grows up as expected by the parents.

Mother who just entered motherhood has new responsibility to learn about parenting skill. Young mothers can be overwhelmed and will need some help 
both in form of information and guidance. Traditionally, guidance and support to new parents have come from family, friends, and health care providers. Social media platforms have potential to promote self-directed learning, particularly by new mother. However, the internet and social media are growing sources of guidance and support for parents [5].

Based on observation, a lot of accounts in social media like to share information about parenting. Besides, many parenting websites offer users the opportunity to join an online community based around a common interest, providing information, support and advice [6]. This phenomenon surely creates different perceptions for each individual.

According to Robbins [7], perception is an impression that is obtained by an individual through the five senses then analysed (organised), interpreted and then evaluated, so that the individual gets meaning.

People must have their own reasons when accessing social media and awareness of its implications. Based on above explanation, this research will further discuss about how young mothers describe their perception towards social media as a source of information or parenting guide.

\section{THEORETICAL FRAMEWORK}

\subsection{Informal Learning}

Informal learning is defined as any activity involving the pursuit of understanding, knowledge or skill which occurs without the presence of externally imposed curricular criteria [8]. A number of attributes of informal learning were compiled by Boekaerts and Minnaert [9] such as open-ended, non-threatening, enjoyable and explorative.

\subsection{Self-Directed Learning}

Self-directed learning can be defined as a process in which individuals take the initiative, with or without the help from others, in diagnosing their learning needs, formulating goals, identifying human and material resources, choosing and implementing appropriate learning strategies, and evaluating outcomes [10]. In selfdirected learning, the learners need to be empowered to make their own learning decisions [11].

\subsection{Online Resources for Self-Directed Learners}

According to Song \& Bonk [12], with the support of emerging technologies, learning is becoming selfdirected and informal. Such opportunities are important to understand since learners often address that their informal learning activities are more motivating and engaging than formal learning [13]. In effects, through online resources particularly social media, self-directed learners manage their time to analyze, implement and evaluate the materials from online resources.

\section{METHOD}

\subsection{Data}

This study engaged a qualitative design to describe mothers' perceptions of social media as source of parenting information. This research was conducted during March-April 2020. The data was obtained through focus group discussion and individual in-depth semistructured interviews. Data were coded into several themes: (1) reasons of using social media as parenting information; (2) types of contents accessed by mothers on parenting accounts; (3) implications of parenting accounts.

\subsection{Participants}

The participants were 24 young mothers age between $24-28$ years old who were selected using purposive sampling technique.

Table 1. Short cut keys for the template

\begin{tabular}{|c|c|c|}
\hline Characteristic & & $\begin{array}{c}\text { Total } \\
\text { Participants } \\
\end{array}$ \\
\hline Location & $\begin{array}{l}\text { Badung } \\
\text { Denpasar }\end{array}$ & $\begin{array}{l}14 \\
10 \\
\end{array}$ \\
\hline Age (years old) & $\begin{array}{l}24 \\
25 \\
26 \\
27 \\
28\end{array}$ & $\begin{array}{c}1 \\
3 \\
12 \\
6 \\
2\end{array}$ \\
\hline Occupation & $\begin{array}{l}\text { Housewife } \\
\text { Private } \\
\text { Employee } \\
\text { Entrepreneur } \\
\text { Civil Servant }\end{array}$ & $\begin{array}{c}2 \\
18 \\
1 \\
3\end{array}$ \\
\hline $\begin{array}{l}\text { Educational } \\
\text { Background }\end{array}$ & $\begin{array}{l}\text { High School } \\
\text { Bachelor } \\
\text { Degree } \\
\text { Master } \\
\text { Degree }\end{array}$ & $\begin{array}{c}2 \\
17 \\
5\end{array}$ \\
\hline Number of child & $\begin{array}{l}1 \\
>1\end{array}$ & $\begin{array}{c}20 \\
4\end{array}$ \\
\hline $\begin{array}{l}\text { Child Age (years } \\
\text { old) }\end{array}$ & $\begin{array}{l}0-1 \\
1-2 \\
2-3 \\
>3\end{array}$ & $\begin{array}{c}8 \\
13 \\
1 \\
6\end{array}$ \\
\hline \multicolumn{2}{|c|}{ Total } & 24 \\
\hline
\end{tabular}




\section{RESULTS}

\subsection{Reasons of Using Social Media as Parenting Information}

Mothers stated that the information from social media parenting accounts follow current issues (up to date) and these accounts also have wide-range of information.

I choose social media because I can spend my time to look for information when my baby is sleeping. On Instagram, there's a lot of parenting accounts and they're really informative and I can look for unlimited information and they also update their content daily.

Social media also considered as cheap option rather than books and it can be accessed anywhere and anytime.

Actually I used to read books when I was pregnant and I got a lot of information from books, but now when raising my son, I prefer to use social media more frequently, because it's more efficient and it doesn't cost that much as long as we have internet connection, we can use it anytime and anywhere.

In addition, mothers like to use social media since it provides visual information like photos and videos. Mothers also talked about the accounts interface:

I like to use Instagram to browse information about parenting because I can get the information through pictures and videos so I don't get bored of reading. Their contents are looking good and attractive.

Based on focus group discussion, it can be seen that there has been a shift in the sources of information on parenting carried out by young mothers today. In the past decades, young mothers often got information about parenting from their parents or neighbors. However, these days young mothers can get information about parenting easilyfrom social media. Mothers use social media to confirm information obtained from other sources, such as from parents or other mom.

\section{Sometimes I'm not so sure about information that I got from my mom or my cousins. That's why I follow parenting accounts on Instagram to check that information. Because we're from different generation and I don't really believe in myth in parenting world, I prefer information that's more scientific and makes sense to me.}

According to mothers, there are some accounts who owned by pediatrician or psychologist. Thus, mothers feel safe when following certain trustworthy information.

I've been following her (a paediatrician account) for few years because she is a doctor and I trust information given by her. I also like to check her Instastory on Instagram because I can get a lot of new information about parenting. She also likes to answer DMs (direct message) that I sent to her so I think I save more money because I get this information for free.

Mothers also appreciate that social media facilitates interaction with other parents. Mothers can get the answer immediately about problems or concern that related to parenting from other parents which considered as supporting each other.

\section{I joined mothers' group on WhatsApp and parenting group called Asianparents on Facebook. We like to exchange information and we don't bother to share their problem or concern about our child. It's interesting to join these groups because we as mothers need this kind of support system.}

\subsection{Types of Contents Accessed by Mothers on Parenting Accounts}

During focus group discussion, there are 3 main contents that mostly accessed by mothers on parenting accounts: (1) Pregnancy; (2) Parenting; and (3) Family life.

Mothers use social media to prepare themselves having a baby and when they get ready for birth.
As a Balinese, I was hoping to have a baby soon after I got married. Parenting accounts on Instagram help me with a lot of information like we need to record our menstrual cycle frequency, monitor the ovulation and manage to have sex during the fertile window, eat healthy food and so on. They also give information on preparing the baby arrival. These information are very useful for mothers who are planning to have a baby.

Social media advice about breastfeeding is considered important for young mothers.

I have difficulties with breastfeeding that's why I tried to find information from parenting accounts. Of course I need to sort the information and some of them work on me, some information did not suit me but that's fine.

Children growth and development during their golden age becomes parents' responsibility and priority. Mothers appreciate that parenting account share MPASI (Makanan Pendamping ASI) or complementary food idea.

As mother, sometimes I got stuck when preparing my child's menu. I often search about MPASI menu with balance amount of nutrition. Not only that, I got many useful information like 
how to stimulate baby because as a parent I want to make sure that my baby grow and develop well.

The last content that often accessed by mothers is about family life. Mother stated that motherhood is a joyful but also tiring.

That's (family life content) also one of the content that I like to see from the parenting accounts. I'm sure every mother must have felt a pressure and stressful situation after giving birth. Parenting account can see that and they give us tips about how to cope with our stress and be grateful as a mom, maintain our health and keep our intimacy with our husband, that's also important, too!

\subsection{Implications of Parenting Accounts}

When mothers talked about the information from social media parenting accounts, they also cannot deny that sometimes the information can be overload.

When I was pregnant, I followed so many parenting accounts, there were almost more than 20 accounts! It makes me overwhelmed because when I know too much, I get more confused and become more difficult to make decisions.

Mothers also explain the need to aware of nonreputable or fake parenting accounts on social media.

If you search parenting account on Instagram, there will be hundreds of account that showed up, from the reputable to the non-reputable accounts. The easy trick, you can see if the account is verified with blue checkmark sign, it means that the account is reputable. You can also check if your friends on Instagram are also following that account. That would be nice!

\section{DISCUSSION}

The themes that emerged reveal that social media can promote young mothers to engage in SDL process. The 'need to know' began since their pregnancy phase and this process continuously happens until their children becoming toddlers and kids. Related the context of parenting, there is alignment between Knowles [10] that in SDL is a response to a specific need for knowledge. Furthermore, according to Knowles [10], there is a lot of mutuality among a group of self-directed learners. This explanation is related to the finding in which social media help to facilitate interaction with other parents and support system to parents with same concerns or problems.

As mentioned, self-directed learners have freedom to select a topic and resources. In this study, participants use social media as learning resources since it does not have a strict situation. Social media have contributed to an information society, and can increase access to learning for people of all ages and potentially across socioeconomic levels across the world [14]. Thus, people can easily become a self-directed learner and make decisions on what information and knowledge are important for them [15].

\section{CONCLUSION}

Based on the previous discussion, it can be concluded that young mothers in Bali are keen to use social media as their parenting guide. This fact shows that they are practicing the self-directed learning which related to decision making during motherhood phase.

As mentioned, motherhood can be very challenging and exciting at the same time. Mothers surely want the best for their child. In this study, young mothers engage in self-directed learning process using social media as parenting information and other types of information such as pregnancy and family life. During this process, it is important for young mothers to be selective and wise when choosing parenting accounts that are reliable and trusted as their source of parenting information.

\section{REFERENCES}

[1] Social media definition, KBBI Daring, https://kbbi.kemdikbud.go.id/entri/media\%20sosial Retrieved on 8 April 2020.

[2] D. M. Boyd, N. B. Ellison, Social network sites: Definition, history, andscholarship, Journal of Computer-Mediated Communication, 13, 2008, 210-230.

[3] J. Petch, W. K. Halford, Psycho-education to enhance couples' transition to parenthood, Clinical psychology review 28(7) (2008) 1125-1137.

[4] J. B. Brooks, The Process of Parenting: Ninth Edition, McGraw-Hill Higher Education, 2012.

[5] R. Y. Moon, et al., Mothers' Perceptions of the Internet and social media as sources of parenting and health information: qualitative study, Journal of medical Internet research, Vol. 21 (7) e14289, 2019. DOI: https://doi.org/10.2196/14289

[6] R. Burrows, et al., Virtual community care? Social policy and the emergence of computer mediated social support. Information, Communication, and Society, 3, 2001, 95-121. DOI: https://doi.org/10.1080/136911800359446

[7] S. P. Robbins, T. A. Judge, Organizational behavior (Vol. 26), New Jersey: Prentice Hall, 2001. 
[8] D. W. Livingstone, Adults' informal learning: Definitions, findings, gaps and future research, NALL Working Paper\# 21, 2001.

[9] M. Boekaerts, A. Minnaert, Self-Regulation with Respect to Informal Learning, International Journal of Educational Research 31(6) (1999) 533-544.

[10] M. S. Knowles, Self-directed learning: a guide for learners and teachers, New York, NY: Cambridge Books, 1975.

[11] S. Downes, New technology supporting informal learning, Journal of Emerging Technologies in Web Intelligence, 2, 2010, pp. 27-33. DOI: https://doi.org/10.4304/jetwi.2.1.27-33

[12] D. Song, C.J. Bonk, Motivational factors in selfdirected informal learning from online learning resources. Cogent Education, 3(1) (2016) 1205838. DOI: https://doi.org/10.1080/2331186X.2016.1205838

[13] A. Jones, et al., Using mobile devices for learning in informal settings: Is it motivating? IADIS International Conference on Mobile Learning, Dublin, IADIS Press, 2016, pp. 251-255.

[14] S. B. Merriam, R. S. Caffarella, Learning in Adulthood: A Comprehensive Guide, San Francisco, CA: Jossey-Bass, 1999.

[15] M. G. Derrick, Creating environments conducive for lifelong learning. New Directions for Adult and Continuing Education, 2003, pp. 5-18. DOI: http://dx.doi.org/10.1002/(ISSN)1536-0717 